\title{
THEORETICAL APPROACHES TO DEFINING JEWISH IDENTITY, AND THE CASE OF FELIX MENDELSSOHN
}

\author{
Daniel R. Langton*
}

It is possible to outline two ways of approaching the subject of Felix Mendelssohn's Jewishness in relation to his oratorio St Paul. Firstly, one can consider certain theoretical considerations that emerge from the field of Jewish Cultural Studies in relation to complex Jewish identity in the modern world. In the light of these considerations, it will be suggested that the St Paul libretto shows the impact of his Jewish heritage and, in fact, demonstrates nicely the messy kind of Jewish self-consciousness that is often of greatest interest to scholars in the field. Secondly, one can consider the context of Jewish approaches to the apostle Paul. Here it will be suggested that Mendelssohn's oratorio can be seen to function in a very similar way insofar as he seems to blur the boundary between Judaism and Christianity.

Felix Mendelssohn (1809-1847) was a grandson of the famous Jewish Enlightenment philosopher, Moses Mendelssohn, and a son of the banker, Abraham Mendelssohn, who had him baptised as a seven year-old. A musical child prodigy who has been frequently compared to Mozart, Felix went on to become a renowned conductor and composer whose work mediated between the Classical and Romantic traditions. ${ }^{1}$ Among the many symphonies, concertos, oratorios, piano and chamber music that he wrote in his short lifetime, two of his most famous works were the oratorios Elijah (1846) and, of greatest interest here, St. Paul (1836). ${ }^{2}$

A passionate debate currently rages amongst scholars as to whether Felix defined himself Jewishly or not. No-one disputes that he was a proud German and a sincere Christian. Rather, the focus of the debate is how important, if at all, Felix's Jewish heritage was to his religious worldview and, by extension, to his work. The history of this controversy is long and not a little sordid. An influential anti-Semitic attack by Wagner in 1850, shortly after Felix's death, had sought to marginalise his works by reference to their perceived Jewish characteristics $^{3}$ and the Nazis took up this theme and went on to ban performances of his

* Professor of the History of Jewish-Christian Relations, University of Manchester. Email: daniel.langton@ manchester.ac.uk This essay has appeared in modified version in Daniel R. Langton, 'Felix Mendelssohn's Oratorio St. Paul and the Question of Self-Identity', Fournal of Jerwish Identities $1 / 1$ (2008) and in the same author's The Apostle Paul in the Fewish Imagination (Cambridge: Cambridge University Press, 2010).

${ }^{1}$ For a comprehensive biographical study, see R. Larry Todd, Mendelssohn: A Life in Music (Oxford: Oxford University Press, 2003).

${ }^{2}$ The first German edition was Felix Mendelssohn-Bartholdy, Paulus (Bonn: N. Simrock, 1836). The first English edition was Felix Mendelssohn, St. Paul (Birmingham: 1837).

${ }^{3}$ Wagner published 'Das Judenthum in der Musik', Neue Zeitschrift fir Musik (Leipzig: 1850) under a pseudonym. He describes Mendelssohn's music as 'vague, fantastic shadow-forms', having already explained that '[a]lthough the peculiarities of the Jewish mode of speaking and singing come out the most glaringly in the commoner class of Jew, who has remained faithful to his fathers' stock, and though the cultured son of Jewry takes untold pains to strip them off, nevertheless they shew an impertinent obstinacy in cleaving to him.' Richard Wagner, Fudaism in Music and other Writings, trans. W. Ashton Ellis (London: University of Nebraska Press, 1995), 89, 96. 
music from 1938. In a classic study by Werner in 1963, the negative value-judgment of Felix's Jewishness was reversed and a portrayal of a great musician was offered that stressed Jewish influences and pride in his Jewish heritage. ${ }^{4}$ However, recent research by Sposato has discredited much of Werner's presentation, showing that he modified the wording of key correspondence in making his case. Sposato argues instead that Felix saw himself as 'enlightened, rationalist, and, in short, a typical German Neuchrist' ${ }^{5}$ as Jewish converts to Christianity were called, brought up and baptised as a Protestant and eventually becoming a follower of the highly influential Reformed theologian Friedrich Schleiermacher (17681834) ${ }^{6}$ with no documented interest in his Jewish ancestry. Certainly, evidence to the contrary is hard to come by and appears to amount to a report that Felix once commented on the irony that he, as a 'Jew-boy', had brought about a revival of the church composer J.S. Bach. ${ }^{7}$ Nevertheless, other scholars, including Botstein, Steinberg and Todd, while accepting Sposato's demolition of Werner's account, continue to regard Felix's Jewish background as important for making sense of the man and his music. All agree that in nineteenth-century German society, Felix could not have avoided his Jewishness even if he had so desired. ${ }^{8}$ But while Sposato stresses that he chose not to define himself as such, the others remain convinced of the importance of his Jewish heritage for understanding him. ${ }^{9}$ In particular, Botstein argues that Felix's lifework was the completion of a 'syncretic' project to 'universalise Judaism', a project first began with his grandfather Moses Mendelssohn. ${ }^{10}$ In fact, there is not as much distance between the two camps as appears at first sight. Sposato's meticulous study is certainly prepared to acknowledge a development in Felix's writing which, by the end of his life, had arrived at what is described as a 'strategy of dual

\footnotetext{
${ }^{4}$ Eric Werner, A New Image of the Composer and his Age, trans. Dika Newlin (New York: Collier-Macmillan, 1963).

${ }^{5}$ Jeffrey S. Sposato, 'Creative Writing: The [Self-] Identification of Mendelssohn as a Jew', The Musical Quarterly 82:1 (Spring 1998), 192.

6 The distinction between the Reformed (Calvinist) and Lutheran churches in Prussia at the time had mainly to do with liturgy. Felix proclaimed himself 'a follower of Schleiermacher' in 1830 in a letter to his friend Julius Schubring, himself a disciple of the theologian who sought to reconcile Lutheran and Reformed theology; he also cultivated a personal friendship with Schleiermacher. Jeffrey Sposato, The Price of Assimilation: Felix Mendelssohn and the Nineteenth-Century Anti-Semitic Tradition (Oxford: Oxford University Press, 2006), 48, 186n39.

7 'To think that it must be a comic-actor and a Jew-boy [Judenjunge] who brings back to the people the greatest Christian musical work!' Eduard Devrient, Meine Erinnerungen an Felix Mendelssohn or My Memories of Felix Mendelssohn (Leipzig: J.J. Weber, 1872), 62.

${ }^{8}$ Spozato himself observes, 'That Mendelssohn identified in part as Jewish is beyond question. How could he not have, with queens, princes, fellow musicians, and friends all, to a greater or lesser extent, seeing him as such?' but he argues forcefully that this was of little or no real consequence. Sposato, The Price of Assimilation, 14.

${ }^{9}$ Steinberg responds directly to Sposato's categorization of Mendelssohn by asserting that 'Felix Mendelssohn's cultural moment and biographical formation cannot be understood as those of a 'typical Neuchrist' but rather as a paradigm of a multicultural and uncertain moment in German Jewish history that was available only to the Biedermeier generation, that is, the generation of 1815-1848. The assertion that Mendelssohn should be considered a Protestant rather than Jew simply replaces one conceptually and historically inadequate label with another.' Michael P. Steinberg, 'Mendelssohn's Music and German-Jewish Culture: An Intervention', The Musical Quarterly 83:1 (Spring 1999), 32. Todd draws upon both Botstein and Sposato, concluding 'we must begin to realize the significance of the composer's own project of assimilation, of finding ground between his adopted faith and the rationalist Judaism of his grandfather, Moses Mendelssohn.' Todd, Mendelssohn: A Life in Music, xxviii.

${ }^{10}$ Writing before Sposato, Botstein's argument (which remains unchanged) was that '[Felix] Mendelssohn was syncretic, not sectarian. His Christian faith focused on the extent to which Christianity was a universalization of Judaism.' Leon Botstein 'The Aesthetics of Assimilation and Affirmation: Reconstructing the Career of Felix Mendelssohn' in R. Larry Todd, ed., Mendelssohn and His World (Princeton: Princeton University Press, 1991), 23.
} 
perspective', that is, 'an attempt to reconcile his Christian faith and his Jewish heritage. ${ }^{11}$ It is agreed, then, that Felix's shifting attitude towards Jews and his consciousness of both Jewish and Christian perspectives - and its implications for his self-understanding - can be traced in his works. For those interested in complex Jewish identity, whatever the precise label given, his oratorio about the Apostle to the Gentiles has some particularly useful insights to offer.

When it comes to defining Jewish identity or 'Jewishness' in a systematic way, one's assumptions play a major role. One tendency, not uncommon among theologians, is to essentialize by classifying people and phenomena as Jewish only in so far as they conform to an assumed essence of a normative Jewishness. This essence may or may not be related to theologically derived criteria such as matrilineal decent, conversion to a particular tradition or set of beliefs, adherence to a certain body of law, a role in salvation history, or to nontheological criteria such as racial, national or cultural characteristics. From this perspective, responsibility for determining Jewish authenticity rests entirely with the observer, irrespective of whether his views originate from within the community or from outside. For the essentialist, anything or anyone who does not correspond to the given definition is to be excluded as marginal at best and deviant at worst. One might imagine a core of authenticity surrounded by concentric circles of ever decreasing legitimacy. The problem, of course, is that observers do not agree on what exactly constitutes the core of authenticity. Whichever definition is to be regarded as authoritative depends upon one's existing biases. Furthermore, proponents of essentialism do not tend to recognise the historically-conditioned nature of such definitions and often assume that the characteristics of Jewish authenticity have remained fundamentally unchanged down through the ages. ${ }^{12}$

An alternative method of categorization is that of 'self-definition', the approved method for many social scientists and historians. This non-essentialist approach does not predetermine the outer limits of Jewishness and so 'deviancy' or 'marginality' are terms free of negative connotations. The inclusion of those who define themselves Jewishly can lead to political controversies, such as the acceptance of Messianic Jews despite their dismissal as Christians-by-another-name by a broad spectrum of the Jewish community. But the advantage of a self-definitional approach is that it largely frees the observer from the responsibility for selection and minimises the projection onto the subject of his own ideological biases. For some, 'self-definition' implies that the individual defines himself primarily in Jewish terms, but this need not be the case. Arguably, an individual can possess a self-image that includes a Jewish component, however he defines it. This is an important point, especially in the context of intercultural studies which take for granted overlapping or hierarchical identities. Nor should one forget that an individual's self-image evolves and transforms in real time and changes according to social context. The self-definitional

\footnotetext{
${ }^{11}$ Sposato suggests that a changing attitude towards Jews is apparent from the time of Felix's revival of the St. Matthew Passion in 1829, through the libretto drafted for A.B. Marx's Mose in 1833 and the oratorios of St. Paul (1836), Elijah (1846), and Christ (1847). The new attitude revealed in the last two works was 'one no longer fuelled by a need to demonize the Jews in order to prove the sincerity of his Christian faith.' Sposato, The Price of Assimilation, $178-179$.

${ }_{12}$ For a powerful critique of the essentializing tendency, see Laurence J. Silberstein, Mapping fewish Identities (New York: New York University Press, 2000).
} 
approach is commonly used because it attempts to accommodate the complex, shifting reality of Jewish identity. ${ }^{13}$

Unfortunately, 'self-definition' excludes many who do not appear to see themselves in Jewish terms and yet who live lives and produce works that strike the sensitive observer as inexplicable without reference to a Jewish dimension of some sort. Celebrated examples include the seventeenth-century philosopher Baruch Spinoza and, of course, Felix Mendelssohn. A work of monumental Jewish scholarship such as the Encyclopaedia Fudaica will include such problematic individuals because of its working principle that 'anyone born a Jew' is qualified for inclusion, even if he later converted or disassociated himself from Jewish life, as are individuals born of only one Jewish parent who are 'sufficiently distinguished. ${ }^{14}$ But no theoretical justification is offered for this approach and it appears to be premised upon unacknowledged essentialist assumptions of a theological and / or racial kind. Is it possible to qualify the self-definitional method, so that a more nuanced treatment of such individuals can be offered that avoids the common essentialist definitions?

The key question, surely, is whether a significant part of an individual's worldview is best explained in terms of his self-identification at some level as a Jew, and whether the failure to take this dimension seriously would result in an impoverished understanding of his life and work. (For present purposes, it does not matter whether the individual's perception of Jewishness or Judaism is real or imagined). For those Jews who later convert to Christianity or who try to disassociate from Jewish life in general, breaking the psychological ties of association is very difficult, if not impossible. This is especially true for those living in the modern period, when the authority of the Church, and its belief in the transformative power of baptism, was losing ground to the natural sciences and the assumption of eternal and fixed species. Mendelssohn, for example, would have been well aware that his contemporaries continued to see in him an indelible trace of Jewishness and, at some level at least, he must have internalised this social reality. One should be wary of underestimating the impact of this kind of 'intersubjective' assessment of Jewishness. ${ }^{15}$ To put it another way, it might be possible to expand the self-definitional approach to include those born Jews who, after leaving the community, continue to self-identify as Jews on some level. The problem is how an observer can know whether the individual so identifies if this association is not articulated explicitly. Arguably, Mendelssohn should be included under the self-definitional approach if a case can be made that an awareness of his identification as a Jew at some level contributes in a significant sense to an understanding of his composition, in this case, the oratorio

${ }^{13}$ For a survey of the changing understandings of Jewishness, especially in the ancient world, see Shaye J.D. Cohen, The Beginnings of Jewishness: Boundaries, Varieties, Uncertainties (Berkley: University of California Press, 1999).

${ }^{14}$ In their introduction the editors write, 'In certain biographical entries a problem was to determine who was a Jew. The first principle adopted was that anyone born a Jew qualified for inclusion, even if he or she had subsequently converted or otherwise dissociated himself from Jewish life (where these facts are known, they are stated). The second principle was that a person with one Jewish parent would qualify for inclusion (with the relevant information stated) if he or she were sufficiently distinguished. A person whose Jewish origins were more remote would only be the subject of an entry in very unusual cases. However, a more generous attitude was taken in the case of Marranos, in view of the special circumstances surrounding their history.' Geoffrey Wigoder and Fern Seckbach, 'Editor's Introduction', Encyclopaedia fudaica, 7.

${ }^{15}$ In this vein Krausz has argued that 'Jewishness is understood as a set of characteristic positions in which certain people are cast or ascribed - by themselves and by others.' Michael Krausz, 'On Being Jewish' in David Theo Goldberg and Michael Krausz, eds., Fewish Identity (Philadelphia: Temple University Press, 1993), 266. 
St Paul. Consequentially, both the subject and the observer must share the responsibility for establishing 'self-definition' because however much depends upon the subject's assumptions, attitudes, value-judgments and ideas, just as much hangs on the observer's ability to uncover and interpret them in their historical context. One can make a useful distinction in this regard between essentialist, ahistorical characteristics of Jewishness and historically- and culturally-determined characteristics of what constitutes Jewishness. ${ }^{16}$ What follows, then, is an attempt to connect Mendelssohn's work to a self-conscious accommodation with his Jewish heritage. It is an attempt to offer a plausible reading of his carefully edited libretto as an expression of religious sentiment that was by no means entirely hostile to Judaism as he conceived it at that time, and which allowed him to identity with it, at some level.

Let us begin with a brief overview of the intellectual influences within Felix's family for the purpose of establishing the foundations of his own religious constitution. One might be tempted to begin with his grandfather, Moses Mendelssohn (1729-1786), ${ }^{17}$ whose writings can be seen as an attempt to relate eighteenth-century rationality and theism. After all, Felix was instrumental, at least at an initial stage, in having Moses' collected works published only four years after the completion of St. Paul. ${ }^{18}$ The book that made Moses' reputation, Phaedon (1767), was a discussion of immortality which drew heavily upon natural theology and assumed the universality of rational thought. ${ }^{19}$ Felix read this extended commentary of Plato's treatise in 1831, only a year before work began on the St. Paul oratorio. ${ }^{20}$ If Felix had also read Moses' classic study, ferusalem or On Religious Power and Fudaism (1783), which also featured a deist-like vision of a God who reveals his purposes and ethical demands through the natural world and by means of a common access to reason, ${ }^{21}$ then this would have important implications for his

\footnotetext{
${ }^{16}$ Krausz maintains that one can 'distinguish between essentialism - the doctrine that there are ahistorically fixed conditions for a thing to be that thing - from what, at particular moments in historical evolution, are taken to be necessary conditions for a thing to be a thing.' Krausz, 'On Being Jewish', 267.

${ }^{17}$ Botstein is among those who would do so. 'Felix Mendelssohn's advocacy of his grandfather's work is certainly positive evidence of his connection to being Jewish. A revival of or an increase in awareness of his grandfather's writings by definition had to invoke a visible affirmation of Felix's Jewish heritage... Felix's knowledge of and lifelong admiration for Moses Mendelssohn's work was nontrivial.' Leon Botstein, 'Mendelssohn and the Jews', The Musical Quarterly 82:1 (Spring 1998), 212.

${ }^{18}$ It is, however, important not to over-estimate Felix's role in this. He was approached to assist with the publication of Moses Mendelssohn's works in 1840, but it was his uncle, Joseph, and Joseph's son Benjamin, who were actually responsible for bringing this product to a successful conclusion. Todd, Mendelssohn: A Life in Music, $16-17$.

19 ' $[\mathrm{T}]$ he endowments he [man] possesses of body and mind, he knows to be the gift of the all-good Father. All beauties, all harmony, goodness, wisdom, providence, ways and means, which he has acknowledged hitherto in the visible and invisible world, he considers as thoughts of the Almighty, which are given him to read in the book of creation, in order to advance him to a higher perfection... [W] fulfil the views of the supreme bring on earth by developing our intellectual capacities... In our eyes the world of moral beings speaks the perfection of its author, as strongly as the world of nature.' Moses Mendelssohn, Phaedon or the Death of Socrates (London: J. Cooper, 1789), 174-175, 181, 197. German original: Moses Mendelssohn, Phaedon oder über die Unsterblichkeit der Seele in drey Gesprächen (Berlin: Stettin, 1767). In an appendix to the third edition, Moses goes so far as to suggest that 'A friend of reason, such as he [Socrates] was, would certainly have gratefully accepted from other philosophers that part of their doctrine which was based on reason, no matter what country or religious party they otherwise belonged to. Where rational truths are concerned, one can agree with anyone, and nevertheless find many things untrustworthy which he accepts on faith.'

20 Todd, Mendelssohn: A Life in Music, 244.

${ }^{21}$ In Ferusalem Moses wrote 'It is true that I recognize no eternal truths other than those that are not merely comprehensible to human reason but can also be demonstrated and verified by human powers... I consider this an essential point of the Jewish religion and believe that this doctrine constitutes a characteristic difference between it and the Christian one... Eternal truths... insofar as they are useful for men's salvation and felicity, are taught by God
} 
conception of the Jewish religion. However, with the exception of Phaedon there is no direct evidence that Felix actually read Moses' works (as Sposato points out), and while it is difficult to imagine that his famous grandfather's writings and ideas were of no interest to the cultivated, intellectual household in which Felix was brought up, one must be cautious about attributing to them too great an influence. ${ }^{22}$ Firmer ground is found with Felix's father, Abraham Mendelssohn-Bartholdy (1776-1835), whom Felix deeply respected and from whom he sought approval throughout his life. The views of the father are important for what they tell us about the kind of religious environment in which the son was actually raised. In common with other assimilationist Jews of his day, Abraham was attracted to a rationalist perspective and his religious worldview was wary of theism of any sort. While he rejected Judaism he did not offer a ringing endorsement of Christianity, either, as he made clear in several letters to his children. In 1820, at around the time of the confirmation of Felix's sister, Fanny, Abraham discussed his conception of religion at some length. ${ }^{23}$ For Abraham the label 'Christian' was a matter of convenience, an appellation adopted for society's sake, and his real concern for his daughter was for her to find happiness in an ethical, dutiful life. Ultimately, the label made little difference for, as he put it elsewhere, 'There are in all religions only one God, one virtue, one truth, one happiness. ${ }^{24}$ In a letter to Felix in $1829,{ }^{25}$ there is again a clear sense of grudging

in a manner more appropriate to the Deity; not by sounds or written characters, which are comprehensible here and there, to this or that individual, but through creation itself, and its internal relations, which are legible and comprehensible to all men. Nor does He confirm them by miracles... but He awakens the mind, which He has created, and gives it an opportunity to observe the relations of things, to observe itself, and to become convinced of the truths which it is destined to understand here below.' Moses Mendelssohn, Ferusalem or On Religious Power and Judaism, trans. by Allan Arkush (New England: Brandeis, 1983), 89, 93. German original: Moses Mendelssohn, Ferusalem oder über religiöse Macht und Fudentum (Berlin: Maurer, 1783). Moses also believed that the revealed Law could likewise be explained in terms of a rational purpose, and could be regarded as 'the foundation for the national cohesion.' Mendelssohn, ferusalem, 126-128.

${ }^{22}$ Sposato notes that in a letter dated February 1842 Felix wrote that he did not possess 'a single page of his [Moses'] writing', which he reads as indicative of a lack of interest. Sposato, The Price of Assimilation, 36.

23 'Does God exist? What is God? Is He part of ourselves, and does He continue to live after the other part has ceased to be? And where? And how? All this I do not know, and therefore I have never taught you anything about it. But I know that there exists in me and in you and in all human beings an everlasting inclination towards all that is good, true and right, and a conscience which warns and guides us when we go astray. I know it, I believe it, I live in this faith, and this is my religion... This is all I can tell you about religion, all I know about it; but this will remain true, as long as one man will exist in the creation, as it has been true since the first man was created. The outward form of religion your teacher has given you is historical, and changeable like all human ordinances. Some thousands of years ago the Jewish form was the reigning one, then the heathen form, and now it is the Christian... We have educated you and your brothers and sister in the Christian faith, because it is the creed of most civilized people, and contains nothing that can lead you away from what is good, and much that guides you to love, obedience, tolerance, and resignation... By pronouncing your confession of faith you have fulfilled the claims of society on you, and obtained the name of a Christian. Now be what your duty as a human being demands of you, true, faithful, good; obedient and devoted till death to your mother, and I may also say to your father, unremittingly attentive to the voice of your conscience,... and you will gain the highest happiness that is to be found on earth, harmony and contentedness with yourself.' Letter from Abraham Mendelssohn to Fanny Mendelssohn (1820) reproduced in Sebastian Hensel, The Mendelssohn Family, trans. by Carl Klingemann, second edition (New York: Harper, 1882), $1: 79-80$.

${ }^{24}$ Letter from Abraham Mendelssohn to Fanny Mendelssohn (1819) reproduced in S. Hensel, The Mendelssohn Family, 1:77.

${ }_{25}$ 'I had learned, and until my last breath will never forget, that the truth is one and eternal; its forms, however, are many and transitory; and so I raised you, to the extent that the constitution under which we then lived permitted it, free from any religious form, which I wished to leave you to your own convictions, should they demand it, or to your choice, based on considerations of convenience. That was not to be, however, and I had to choose for you. Given the scant value I place on all [religious] forms, it goes without saying that I felt no inner calling to choose for you the Jewish, the most obsolete, corrupt, and pointless of them [all]. So I raised you in the Christian, the purer 
necessity in raising his children as Christians, as dictated by the bigotry of wider society, ${ }^{26}$ even if an outmoded Judaism, as he saw it, was entirely out of the question. For Abraham, 'religion' was, in essence, a universal ethic towards which humankind is progressing that had once been clothed in the apparel of Judaism and was now wrapped in the garments of Christianity. It was a historical view of religion that simultaneously linked Judaism and Christianity but went beyond them, and, arguably, Abraham did not see his conversion (six years after his son's baptism) or change of name (to Mendelssohn-Bartholdy) as a rejection of Moses Mendelssohn's core values, but rather as a continuation or extension of them, the fulfilment of an ideological trajectory; for him, the Mendelssohn name symbolized 'Judaism in transition'. ${ }^{27}$ This schema of a transitional relation between Judaism and Christianity is worth noting because, as will become clear, it was implicit in Felix's composition of St. Paul, despite the fact that the connection was minimised by the Lutheran and Reformed theologies with which he publicly associated himself.

Let us restrict ourselves to two general questions. What themes can be derived from the texts selected by Felix? And what should be made of the materials and corresponding themes that he chose not to include?

Firstly, the materials chosen. Many commentators, both in Felix's day and afterwards, have complained about the amount of space devoted to the martyrdom of Stephen. ${ }^{28}$ After all, the dramatic potential for Saul, such as it is, lies in his (very marginal) involvement in the

[form] accepted by the majority of civilised people, and also confessed the same for myself, because I had to do myself what I recognized as best for you.' Letter from Abraham Mendelssohn to Felix Mendelssohn (1829). M. Schneider, Mendelssohn oder Bartholdy? (Basel: Internationale Felix-Mendelssohn-Gesellschaft, 1962), 18-19, cited in Sposato, The Price of Assimilation, 16.

${ }_{26}$ Abraham discussed the matter with his wife's brother, who had changed his name from Salomon to Bartholdy, and who apparently convinced him to do likewise in correspondence: 'You say you owe it to the memory of your father [to remain a Jew] - do you think you have done anything evil by giving your children the religion which you consider the best one for them? Rather it is an act of homage which you and I and all of us owe to Moses Mendelssohn's efforts in the interests of true Enlightenment... A man can remain loyal to an oppressed, persecuted religion; he can impose it on his children as a candidature for a lifelong martyrdom - as long as he thinks that it alone will bring salvation. But as soon as he no longer believes that, it is barbarism to do anything of the kind.' Letter to Abraham Mendelssohn (undated) reproduced in S. Hensel, The Mendelssohn Family, 1:75.

27 Abraham wrote to Felix, 'My father felt that the name Moses den Mendel Dessau would handicap him in gaining the needed access to those who had the better education at their disposal. Without any fear that his own father would take offence, my father assumed the name Mendelssohn. The change, though a small one, was decisive. As Mendelssohn, he became irrevocably detached from an entire class, the best of whom he raised to his own level. By that name he identified himself with another group. Through the influence which, ever growing, persists to this day, the name Mendelssohn acquired great authority and a significance which defies extinction. This, considering that you were reared a Christian, you can hardly understand. A Christian Mendelssohn is an impossibility. A Christian Mendelssohn the world would never recognise. Nor should there be a Christian Mendelssohn; for my father himself did not want to be a Christian. "Mendelssohn" does and always will stand for a Judaism in transition, when Judaism, just because it is seeking to transmute itself spiritually, clings to its ancient form all the more stubbornly and tenaciously, by way of protest against the novel form that so arrogantly and tyrannically declared itself to be the one and only path to the good.' Letter from Abraham Mendelssohn to Felix Mendelssohn (8 July 1829) reproduced in Michael P. Steinberg, 'Mendelssohn's Music and German-Jewish Culture: An Intervention', The Musical Quarterly 83:1 (Spring 1999), 37-38.

${ }^{28}$ In fact even his father, Abraham, complained, but Felix's polite reply (included within a letter to his sister) does not offer any explanation. 'The non-appearance of St. Paul at the stoning of Stephen is certainly a blemish, and I could easily alter the passage in itself; but I could find absolutely no mode of introducing him at the time, and no words from him to utter in accordance with the Scriptural narrative; therefore it seemed to me more expedient to follow the biblical account, and to make Stephen appear alone. I think, however, that your other censure is obviated by the music; for the recitative of Stephen, though the words are long, will not occupy more than two or three minutes, - or including all the choruses - till his death, about quarter of an hour.' Letter from Felix Mendelssohn to Rebecca Dirichlet (23 December 1834) reproduced in P. and C. Mendelssohn Bartholdy, eds., Letters of Felix Mendelssohn Bartholdy, 62-63. 
murder of a Christian saint and his consequent inauguration as a persecutor of the new sect - and this might easily have been dealt with in fewer than the eleven sections it actually takes. However, one key theme to emerge is that of the contrast between the ideas of the Jews, whose religion was focused on the Law and Temple, and Stephen's more spiritual conception of the nature of their God as the creator of the natural world. ${ }^{29}$ To begin with, Felix reproduces the testimony of the Jewish false witnesses, who shout 'We verily have heard him blaspheme against these holy places, and against the law' (Acts 6:14), and has 'the Jews' as a group express similar complaints. ${ }^{30}$ In recounting the speech that Stephen made in response, about the rebellious history of the Hebrews, Felix is especially careful to include the passages in Acts which condemns them for idol worship ${ }^{31}$ and where the importance of the Temple is denigrated, drawing attention instead to God's sovereignty over nature. ${ }^{32}$ This key theme of God as Creator of the natural world is reinforced by the choice of the text for the first chorus of the oratorio, which exclaims, 'LORD, Thou alone art God; and Thine are the heavens, the earth and the mighty waters' (Acts 4:24). But Felix is not critical of the Jews alone. In a later episode in Lystra in which Paul is mistaken by pagans for a god after having performed a healing, a similar critique is made of the Gentiles who appear even more confused about the nature of God than had the Jews. Felix cites at length Paul's rebuke to the Gentiles' intention to sacrifice to and adore him as a god, which includes his warning that:

you should turn away from all these vanities unto the ever living God, who made the outstretched heavens, the earth and the sea. As saith the Prophet: 'All your idols are but falsehood, and there is no breath in them. They are vanity, and the work of errors: in the time of their trouble they shall perish.' God dwelleth not in temples made with human hands. (Acts 14:15; Jeremiah 10:14,15; Acts 17:24)

Felix immediately follows this with Paul's question, 'For know you not that ye are His temple, and that the spirit of God dwelleth in you?.. For the temple of God is holy, which temple you are' (1 Corinthians 3:16,17). ${ }^{33}$ As if to drive home the errors of the Jewish and pagan conceptions of deity, Felix has the Jews and Gentiles (who do not appear in the biblical text) come together to assault Paul in a joint chorus in section 38,

This is Jehovah's temple. Ye children of Israel, help us. This is the man who teacheth all men, against the people, against this place, and also our holy law. We have heard him speak blasphemies against the law. He blasphemes God. Stone him. (Acts 21:28)

Thus Felix's editorial choices imply that Jew and Gentile alike have misunderstood the nature of God, and have set up idols, temples and laws as a result of their ignorance of the

\footnotetext{
${ }^{29}$ Sposato sees this critique of the Jewish obsession with the Law as evidence of anti-Semitism (which he prefers to the term 'anti-Judaic' in this context). Sposato, The Price of Assimilation, 10-11.

${ }^{30}$ Now this man [Stephen] ceaseth not to utter blasphemous words against the law of Moses, and also God... He hath said, and we have heard him, [that] Jesus of Nazareth He shall destroy all these our holy places, and change all the laws and customs which Moses delivered us. (Acts 6:11, 14).

31 'But they refused him [Moses] and would not obey his word, but thrust him from them, and sacrificed to senseless idols' (Acts 7:39-40).

${ }^{32}$ Solomon built Him an house; albeit the Most High God dwelleth not in temples which are made with hands; for heaven is His throne, and earth is but His footstool. Has not His hand made all these things? (Acts 7:47-48)

${ }^{33}$ This is followed by a chorus that confirms, 'But our God abideth in heaven: His will directeth all the world. We bow to only His decree, Who made the skies, the earth and sea' (Psalm 115:3).
} 
true Creator of the Universe. ${ }^{34}$ In contrast, Felix projects onto Paul (and Stephen) a deist-like admiration of the divine watchmaker, whose temple is to be found within man and who is properly worshipped through the spiritual appreciation of nature, as suggested by the paean of praise of God as the source of all knowledge that ends the first part of the oratorio. ${ }^{35}$ What is of significance here is that Felix's particular understanding of Christianity as the path towards universal, rational enlightenment is by no means an obvious emphasis for a treatment of the life of St. Paul. To explain it, one might look to the foundational influence of his family. For while the kind of belief that characterises the oratorio has been described quite reasonably by Mercer-Taylor as 'an aesthetically blank lowest common denominator of the Christian community in the act of worship', ${ }^{36}$ its assumptions concerning the rationalist underpinnings of religion and the shortcomings of its Jewish garb might as easily be said to have characterised the letters that Abraham Mendelssohn, the assimilated Jew, wrote to his children. ${ }^{37}$ Likewise, in attempting to explain the theme of natural religion one is sorely tempted to consider the parallels to Moses Mendelssohn's famous adherence to a God who reveals his universal will to those who can detect it by observation of his creation, rather than find its source in Lutheran 'philo-Heathenism'38 (a theory which does not take account of Felix's criticism of Gentiles, too). Of course, an interest in natural religion was very much in line with the wider German Enlightenment zeitgeist, and there is nothing remarkable about finding in the work of any composer of this time the rationalist emphasis characteristic of contemporary theology and philosophy of religion. But the point is that, for a Mendelssohn at least, such ideas were not regarded as being in opposition to Fudaism. While the origin of such emphases must remain the subject of speculation, it is reasonable to suggest that Felix's conception of religion had been shaped by the Mendelssohn family's well-documented commitment to rational, universalist religion. In particular, his was a vision consistent with Abraham Mendelssohn's belief in a universal ethic that, in Paul's day, had progressed beyond the culturally determined limitations of paganism and ancient Judaism, and which would

34 Sposato observes that, in the libretto, Gentiles respond more positively to Paul's missionary endeavours than do the Jews, and he suggests that this reflects a typical tendency of Lutheran and German Protestantism to glorify their Gentile heritage, which he calls 'philo-Heathenism'. Sposato, The Price of Assimilation, 92-94. But the reading of the libretto adopted here sees Mendelssohn equally critical of the shortcomings of Jewish legalism and Gentile idolatry.

35 ' $\mathrm{O}$ great is the depth of the riches of wisdom and knowledge of the Father! How deep and unerring is He in His judgements! His ways are past our understanding. Sing to His glory forever more: Amen.' (Romans 11:33)

${ }_{36}$ Peter Mercer-Taylor, 'Rethinking Mendelssohn's Historicism: A Lesson from St Paul', The Fournal of Musicology 15:2 (Spring 1997), 227.

37 Botstein makes a similar observation regarding the source for Felix's rationalism. 'Insofar as Mendelssohn actually succeeded in integrating a Judaic element in the Protestant theology of the text of St. Paul Julius Schubring provided him, it was in the highlighting, through the choral numbers, of the abstract and rational substance of faith. Despite the prominence of the figure of Christ in St. Paul and the centrality of the conversion, it is the rational, ethical essence of faith that stands out... St. Paul represented Mendelssohn's musical-dramatic defence of the theological stance of Abraham Mendelssohn, who ultimately converted to Christianity himself. In St. Paul, baptism is the route to a rational enlightenment.' (Botstein overestimates the role of Schubring and exaggerates the prominence of Christ in the libretto). Leon Botstein, 'Songs without Words: Thoughts on Music, Theology, and the Role of the Jewish Question in the Work of Felix Mendelssohn', The Musical Quarterly 77:4 (Winter 1993), 574575 .

${ }^{38}$ Sposato attributes the theme of 'natural religion' to a German tradition that denigrated Judaism's significance for the Gentiles. In particular, he observes that both Luther and Schleiermacher had believed that God had revealed his law in nature, and therefore 'most of it... was also written into the hearts of the Gentiles before their conversion, thereby inviting Germans to view their ancestors not just as pre-Christian, but as proto-Christian, and therefore a people they could look back on with pride and respect.' The Price of Assimilation, 93-94. 
undoubtedly move on again in time. Nor was it a view that necessarily did violence to Moses Mendelssohn's conception of Judaism as an essentially rational religion.

In addition to Felix's critique of Judaism's misplaced confidence in the Temple and the Law, and his portrayal of the rebellious character of the Hebrews as described in Stephen's speech, the oratorio provides further evidence of its author's negative attitude towards ancient Jewry. ${ }^{39}$ Sposato has demonstrated how, through successive drafts of section 38, Felix eventually replaced the biblical account of Gentile opposition with that of an essentially Jewish opposition. ${ }^{40}$ Furthermore, in the space of a few sections, Felix has the chorus of Hebrews twice chant Leviticus 24:16, in which the Law demands death for blasphemy. ${ }^{41}$ And early in the second part, Felix focuses on the envy of the Jews at Paul's popularity with the masses, their arguments with him, and eventually their conspiracy to ambush and kill him. Furthermore, several choruses of Jews vigorously assert their rejection of the Saviour and their hostility to Paul and 'all deceivers'. ${ }^{42}$ This negative portrayal of the Jews has been put down to the influence of Abraham Mendelssohn ${ }^{43}$ or to the concerns of a Neuchrist to distance himself from the ancestral faith of which he was all too self-conscious. (As such, it is a phenomenon closely related to that of Jewish self-hatred, a topic of great interest within Jewish cultural studies). In any case, it represents a mechanism by which Felix can explain the apostle's momentous decision to turn from the Jews to the Gentiles, which is the point of sections 23-31. It concludes with his famous parting shot,

Ye were chosen first to have the word of the Lord set before you; but, seeing that ye put it from you, and judge yourselves unworthy of the life everlasting, behold ye, we turn, even now, unto the Gentiles. (Act 13:46)

This leads us to two related themes which were more significant to Felix than the failings of the Jews, namely, (i) the universalization of the knowledge of the one true God and (ii) the sacrifice and martyrdom that made this possible, in his mind. The theme of sacrifice is very

\footnotetext{
${ }^{39}$ According to Sposato, Mendelssohn 'tried to distance himself from his [Jewish] heritage as much as possible... The editorial practices in his sacred music libretti also support this view of Mendelssohn, containing as they do numerous examples of the composer unnecessarily including anti-Semitic texts, such as that in the chorus 'His blood be upon us and our children' in his edition of St. Matthew Passion and those that add to his stereotypical depiction of the Jews as a law-obsessed people in Paulus.' Jeffrey S. Sposato, 'Creative Writing: The [Self-] Identification of Mendelssohn as a Jew', The Musical Quarterly 82:1 (Spring 1998), 204. For Sposato, this anti-Jewish strain is enough to demonstrate Felix's rejection of a Jewish identity, at least at the time of writing his Paulus. But this is to dismiss the complex, racial understanding of 'Jewishness' in nineteenth-century European Semitic discourse. Sposato himself observes that Felix's attitudes towards the Jews shifted throughout his lifetime, from which some might infer a lifelong struggle with a Jewish self-identification. Thus Felix's negative representation of the Jews in Paulus could be plausibly interpreted as an antagonistic posture adopted for complicated psychological and social reasons that reflect the complex reality of the Jewish conversion existence at that time and place, rather than simply as evidence that he did not self-identify as a Jew.

${ }^{40}$ Jeffrey S. Sposato, 'Mendelssohn, 'Paulus', and the Jews: A Response to Leon Botstein and Michael Steinberg', The Musical Quarterly 83:2 (Summer 1999), 284-288.

${ }^{41}$ The first Hebrew chorus is 'Take him away. For now the holy name of God he hath blasphemed; and he who blasphemes Him, he shall perish' while the second is 'Stone him to death. He blasphemes God; and who does so shall surely perish. Stone him to death.'

42 One chorus sings "Thus saith the Lord, 'I am the Lord, and beside me there is no Saviour" (Isaiah 43:11) and another 'Is this he, who, in Jerusalem, destroyed all calling on that name which here he preacheth? May all deceivers ever be confounded! Force him away!' (Acts 9:21).

43 'By far the strongest influence on Paulus's treatment of the Jews was [Felix] Mendelssohn's father... [D] uring Felix's youth, Abraham Mendelssohn continually encouraged his son to separate himself from his Jewish roots, both through instruction and by example.' Sposato, The Price of Assimilation, 90.
} 
important and helps account for the structure of the oratorio and even for his interest in Paul in the first place. It is implicit in the death of Stephen himself, whose martyrdom was necessary in order to put Paul on the path to becoming the Apostle to the Gentiles, and whose story, as already noted, seems to have been given disproportionate attention. ${ }^{44}$ The divinely ordained enlightenment of the Gentiles is a phenomenon referred to repeatedly throughout the work ${ }^{45}$ and is emphasised in the opening chorus of the second part, which pre-empts Paul's rejection of the Jews: 'The nations are now the Lord's'. ${ }^{46}$ Felix's interest in the cost of universalization also explains the length of the conclusion, which is devoted to Paul's farewell to the elders of Ephesus. While not offering much in terms of drama, these final sections are replete with references to Paul's readiness to suffer death in the cause of taking the gospel message throughout the world. ${ }^{47}$ Some commentators have complained at Felix's tendency toward sentimentalism, and, arguably, the final sections could be regarded as an over-indulgent expression of the pathos of Paul's life. Building a case for the influence of Christian influence, Sposato has seen here confirmation of his Christological concerns. ${ }^{48}$ But it also ties together Moses Mendelssohn's emphasis on the universality of religious truth, and Abraham Mendelssohn's painful conviction of the necessity of severing his children's ties to the outmoded religious language of Judaism in favour of Christianity. There's no hard evidence, of course, and I may be quite wrong, but it is at least psychologically plausible that Felix's meditation (on the sacrifice necessary to achieve universal knowledge of the one true God) is the result of an acute awareness of what 'Judaism in transition' really means, at least in the experience of the Mendelssohn family.

\footnotetext{
${ }^{44}$ Felix also chooses to include the references in Stephen's speech relating the persecution and suffering of God's messengers: 'Which of the Prophets have not your fathers persecuted? And they have slain them which showed before the coming of Him, the Just one, with whose murder ye have here been stained' (Acts 7:52) and a similar gospel passage, 'Jerusalem, Jerusalem, thou that killest the Prophets, and stonest them which are sent unto thee' (Matthew 23:37).

${ }_{45}$ Texts that Felix uses to allude to the Gentiles' salvation include: Acts 4:26,29 ('And the kings of the earth took their stand and the rulers were gathered together against the Lord and against his Christ... And now, Lord, take note of their threats, and grant that Your bond-servants may speak Your word with all confidence'); Isaiah 60:1,2 ('Arise, shine; for your light has come, And the glory of the LORD has risen upon you. For behold, darkness will cover the earth And deep darkness the peoples; But the LORD will rise upon you And His glory will appear upon you'); Revelation 6:15 ('Then the kings of the earth and the great men and the commanders and the rich and the strong and every slave and free man hid themselves in the caves and among the rocks of the mountains'), 15:4 ('Who will not fear, O Lord, and glorify Your name? For You alone are holy; For all the nations will come and worship before you, for your righteous acts have been revealed'); Romans 10:15,18 ('How will they preach unless they are sent? Just as it is written, "How beautiful are the feet of those who bring good news of good things"... But I say, surely they have never heard, have they? Indeed they have; "their voice has gone out into all the earth, and their words to the ends of the world"'); Acts 13:47 ("For so the Lord has commanded us, "I have placed you as a light for the gentiles, that you may bring salvation to the end of the earth." '), 2:21 ('And it shall be that everyone who calls on the name of the Lord will be saved'); 2 Timothy 4:17 ('But the Lord stood with me and strengthened me, so that through me the proclamation might be fully accomplished, and that all the Gentiles might hear; and I was rescued out of the lion's mouth'); 1 John 3:1 ('See how great a love the Father has bestowed on us, that we would be called children of God; and such we are For this reason the world does not know us, because it did not know Him').

46 'The nations are now the Lord's; they are His Christ's. For all the Gentiles come before Thee and shall worship Thy name. Now are made manifest Thy glorious law and judgements.' (Revelation 11:15, 15:4)

${ }^{47}$ Including: 'Bonds and affliction abide me there [in Jerusalem]; and ye shall see my face no more' (Acts 20:23,25), 'For I am prepared not only to be bound, but also to die at Jerusalem, for the name of the Lord our saviour Jesus Christ' (Act 21:13), and 'And though he be offered upon the sacrifice of our faith, yet he hath fought a good fight... Henceforth there is laid up for him a crown of righteousness' (2 Timothy 4:7,8).

${ }^{48}$ Sposato recognises the theme of sacrifice but does not make the link to universalism and interprets it as evidence of the influence of contemporary Christological models that see the hero, be it Moses or Paul, as the suffering servant of God whose suffering is brought about by the Jews. Sposato, The Price of Assimilation, 92.
} 
Secondly, there is the issue of materials and themes left out by Felix. To anyone familiar with Lutheran understandings of Paul and his life-story, as derived from the book of Acts and his letters, the absence of an explicit reference to the Pauline doctrine of faith alone, or to his abrogation of the Law in that context, or to original sin, or to the Jerusalem Council's decision, after heated debate, to accede to Paul's position that the Gentiles were equally acceptable to God, is puzzling, to say the least. ${ }^{49}$ Such omissions were undoubtedly deliberate, as we can see in a complaint that one contributor to the libretto, Schubring, made after Mendelssohn's death.

That he [Mendelssohn] would not accept my suggestions for the Pauline doctrine of the justification by faith, but, at the appropriate place, substituted merely the general assertion: 'Wir glauben all an einen Gott' [We all believe in one God] was something that did not satisfy my theological conscience, though, perhaps, any extension of the work in this direction would have made it too long. ${ }^{50}$

Put another way, one might ask: to what does Paul convert? Not, as one might have expected from the pen of a convert to Lutheranism, to an understanding of justification by God's grace, and salvation by faith alone in the divine Christ. In fact one is struck by the particular presentation of Jesus. ${ }^{51}$ Next to nothing is said of Jesus' messianic role or of his redemptive sacrifice $^{52}$ and, certainly, the gloriously powerful cosmic Christ of the Pauline epistles does not emerge from the text. Rather, Jesus is referred to in the context of bringing an end to the Temple and the Law (section 5) and is associated as a martyr with Stephen (section 6). Admittedly, Christ is also seen by Stephen in a vision standing by the side of the Father (section 6), and the unconventional use of women's voices to represent the words of the ascended Christ on the road to Damascus certainly produces an ethereal, otherworldly effect (section 14). But this only reinforces the impression that the heavenly Jesus is met only in the subjective visions of men, and there is some evidence that Felix was well aware that such a presentation would be criticised by Protestant theologians. ${ }^{53}$ Thus the familiar Lutheran

${ }^{49}$ The doctrine of justification by faith alone, that is, the teaching that salvation is brought about through faith in God's grace rather than through works of righteousness, is derived from an interpretation of Ephesians 2:8 ('For by grace you have been saved through faith; and that not of yourselves, it is the gift of God'), an interpretation famously championed by Martin Luther. Accounts of the debate of the early church in Jerusalem are given in Acts 15 and in Galatians 2. Its leader, James, ruled: 'Therefore it is my judgment that we do not trouble those who are turning to God from among the Gentiles, but that we write to them that they abstain from things contaminated by idols and from fornication and from what is strangled and from blood. For Moses from ancient generations has in every city those who preach him, since he is read in the synagogues every Sabbath.' (Acts 15:19-21).

${ }^{50}$ Julius Schubring, 'Reminisences of Felix Mendelssohn-Bartholdy' reproduced in Todd, ed., Mendelssohn and His World, 230. The particular formulation 'We all believe in God' is from a hymn by Martin Luther but Schubring, at least, did not regard it as providing an appropriate emphasis of the doctrine of justification by faith alone.

${ }^{51}$ I am grateful to Canon John Davies, formerly of the University of Southampton, for this observation. Admittedly, this is a somewhat subjective claim since others do identify Christ as a focus to the work. Botstein notes 'the prominence of the figure of Christ in St. Paul', referring primarily to the female chorus, and Sposato sees the sacrificial ('suffering servant') motif as Christological in origin. Botstein, 'Songs without Words', 574. Sposato, The Price of Assimilation, 92.

52 Except for three citations of Matthew, the Gospels are completely ignored. Mendelssohn's overwhelming preference is for the Book of Acts (77 citations), in which very little is offered in the way of direct quotations of Jesus.

${ }^{53}$ Felix appears to have been aware that in his revision of the conventions he was sailing close to the wind, theologically speaking, and was courting the condemnation of those who might be suspicious of his religious motives. Schubring recalled that his own suggestion that the voice of Christ be set for four parts ('he [Felix] could not reconcile himself to the notion of producing the effect of a very powerful bass voice'), had a strange effect on Felix: 'After looking at me for a long time, he said: "Yes, and the worthy theologians would cut me up nicely for 
reading of Paul that emphasised God's grace as made manifest in the life, death and resurrection of Christ, who redeems the inhabitants of a fallen world through faith alone, is conspicuous by its absence. Jesus appears primarily as a liberator from misguided, outward religion and thereby as a pioneering exemplar for Stephen and Paul.

Felix's portrayal of Paul's story is focused on a God who exists on a plane far beyond the reach of idol or Temple and whose Laws are better observed from the natural world than from the Torah. Furthermore, it champions an understanding of faith that assumes an unchanging ethical core which, from time to time, requires liberation from the religious misunderstandings and theological confusions that human minds (Jewish and Gentile) have accrued over time. The parallels with the views of his father (and grandfather) suggest some obvious sources of influence. But could one not argue that the themes of the libretto could just as likely be explained by more widespread Protestant beliefs? Sposato and Todd both see this particular oratorio as representative of a stage in Felix's life-story when he was concerned to demonstrate his Christian credentials and to achieve his father's goal of assimilation into Prussian society. ${ }^{54}$ But contemporary German Lutheran theology, while undoubtedly in intellectual ferment and however varied, can arguably be said to have had offered little in way of encouragement in these directions. On the contrary, one might point to the emergence of Lutheran Confessionalism in the 1830s and 1840s, that is, a movement away from the idea of the Church as the universal Body of Christ and toward a distinctive identity based on traditional Lutheran doctrine and exclusive church worship. Mendelssohn's apparent inclinations towards universalism and even a kind of rationalist, natural religion, as found in St Paul, strained against such intellectual currents. The same might be said in relation to the prominent Reformed theologian Friedrich Schleiermacher, a personal friend of Mendelssohn. ${ }^{55}$ On the one hand, Schleiermacher recognised that Christianity could claim no monopoly on revelation, believed it impossible to formulate a theology which was valid for all time, and regarded the articles of Christian belief as edifying expressions rather than fixed proofs - all ideas with which Mendelssohn could sympathise. On the other hand, Schleiermacher also gave absolute prominence to Christ in his theology, denied any

wishing to deny and supplant Him who arose from the dead."' But he went ahead anyway and had Christ's words set to a four-part female chorus, which did provoke some theological complaints. The composer, 'who was well aware of the circumstance, laughed, but did not say much.' Julius Schubring, 'Reminisences of Felix MendelssohnBartholdy' reproduced in Todd, ed., Mendelssohn and His World, 231-232. The other-worldly effect has also been explained as an example of Jewish influence. According to Heinrich Jacob, Felix had applied the commandment 'Thou shalt make thee no graven images' to his music, utilising a device that stressed the great distance between Man and God. Heinrich E. Jacob, Felix Mendelssohn and His Times, trans. Richard and Clara Winston (New Jersey: Prentice Hall, 1963), 217.

54 Todd concludes that 'The completion of the oratorio [Paulus] and its successful reception were critical steps towards achieving Abraham's cherished agendum - full assimilation of his family into Prussian society.' Todd, Mendelssohn: A Life in Music, 338. Sposato writes that 'Mendelssohn, in this, his first oratorio, tried to assuage real or imagined doubts about his Christian faith by writing a work that conformed to popular expectations, both through its call for the conversion of the nonbelievers and its depiction of the narrow-mindedness of those who refuse to see the light (namely, the Jews). Paulus also demonstrates, however, the mental anguish that such a depiction caused Mendelssohn, anguish that led to his eventual reevaluation of this approach... Mendelssohn's tendency to depict the Jews negatively in Paulus derived from an overwhelming personal desire to assimilate into German Christian culture.' Sposato, The Price of Assimilation, 79, 88.

${ }^{55}$ Felix proclaimed himself 'a follower of Schleiermacher' in 1830 in a letter to his friend Julius Schubring, himself a disciple of the theologian who sought to reconcile Lutheran and Reformed theology; he also cultivated a personal friendship with Schleiermacher. Jeffrey Sposato, The Price of Assimilation, 48, 186n39. 
meaningful continuity between Judaism and Christianity (dismissing Judaism as almost entirely without value), and emphasised religious feeling over and against what he saw as the simplistic rationalism of natural theologians and deists - ideas which seem at odds with the reading of the theology underlying the libretto given here. ${ }^{56}$

Finally, it is useful to consider Felix's treatment of the apostle in the context of Jewish approaches to Paul more generally. However counter-intuitive it may seem, Mendelssohn's treatment of Paul is entirely inline with a number of Jewish commentaries on Paul and, in particular, with several artistic Jewish renderings of the apostle in the modern period, including those of a painter, a playwright, and two novelists. ${ }^{57}$ Their treatments, like Mendelssohn's, tended to reflect highly idiosyncratic views of the two religions, and the underlying themes of the oratorio resonate powerfully in their works. In a context where the centuries-old rules no longer seem to apply, there was a shared need to map out the relationship between Jews and Gentiles. For those who inhabited the religious and cultural borderlands, there was a common struggle to achieve a coherent, satisfactory resolution, and a feeling that Paul was a figure close to the heart of the issue. But above all, the key concern was whether or not there existed a common religious essence between Judaism and Christianity. It is worth noting that the majority agreed that there was, despite maintaining that Paul was responsible for the 'parting of the ways'. Its precise nature was described variously in their treatments of the apostle in terms of an underlying rationality, or prophetic inspiration, or complementary manifestations of the spirit of God, or a universal brotherhood of faith. It may be correct to limit what Sposato has described as Mendelssohn's 'attempt to reconcile his Christian faith and his Jewish heritage' to the later oratorio Elijah, ${ }^{58}$ but it seems

\footnotetext{
${ }^{56}$ Schleiermacher wrote that 'Christianity... is essentially distinguished from other such faiths by the fact that in it everything is related to the redemption accomplished by Jesus of Nazareth... Christianity cannot in any wise be regarded as a remodelling or a renewal and continuation of Judaism... Neither can it be said that purer original Judaism carried within itself the germ of Christianity... [Except for prophecy] almost everything else in the Old Testament is, for our Christian usage, but the husk or wrapping of its prophecy, and that whatever is most definitely Jewish has least value'. Friedrich Schleiermacher, The Christian Faith, trans. by H.R. Mackintosh and J.S. Stewart (Edinburgh: T\&T Glark, 1999), 52, 61, 62. German original: Der christliche Glaube (Berlin: 1821-22). For Sposato, Schleiermacher's anti-Judaic sentiments are indicative of Mendelssohn's own position. Sposato, The Price of Assimilation, 93-94. Schleiermacher's attitude towards natural religion and the 'empiricism' of deism was highly critical: 'The essence of natural religion actually consists wholly in the negation of everything positive and characteristic in religion and in the most violent polemic against it.' Friedrich Schleiermacher, On Religion, trans. Richard Crouter (Cambridge: Cambridge University Press, 1988), 192, 207. German original: Reden über die Religion (Berlin: 1799). This attitude stems from his central project, as described by one commentator: 'The way in which God is apprehended in the immediacy of feeling of utter dependence... leads [Schleiermacher] to a conception of the relation of God and the world which does not fit into the common classifications of deism, theism, pantheism... He was plainly seeking a view beyond naturalism and supernaturalism. Deism was obviously abhorrent, for it posits an externality of God to the world and the self that is utterly at odds with the feeling of utter dependence, and makes God only "a being."' Claude Welsch, Protestant Thought in the Nineteenth Century: 1799-1870 (New Haven: Yale University Press, 1972), I:79.

${ }^{57}$ Ludwig Meidner, 'Pauluspredigt' (Paul's Sermon, 1919), watercolour, 68x49cm. Buller Collection, Duisberg. Franz Werfel, Paulus unter den Fuden (Berlin: Zsolnay, 1926). Sholem Asch, The Apostle, trans. by Maurice Samuel (London: Macdonald, 1949). Samuel Sandmel, The Apostle Paul: A Novel (unpublished, undated), 472pp, in Samuel Sandmel Papers, Manuscript Collection No. 101, Series C/1/17.7 and 18.1 at the American Jewish Archives, Cincinnati, U.S.A.

${ }^{58}$ Sposato suggests that a changing attitude towards Jews is apparent from the time of Felix's revival of the St. Matthew Passion in 1829, through the libretto drafted for A.B. Marx's Mose in 1833 and the oratorios of St. Paul (1836), Elijah (1846), and Christ (1847). The new attitude revealed in the last two works was 'one no longer fuelled by a need to demonize the Jews in order to prove the sincerity of his Christian faith.' Sposato, The Price of Assimilation, 178-179.
} 
reasonable to trace this activity back to his earlier study of St Paul, too. If that is indeed the case, then it is worth pointing out that this struggle is by no means unique to this Protestant composer of Jewish heritage - it is arguably a characteristic concern of a number of Jewish engagements with the Apostle to the Gentiles in the modern period.

\section{BIBLIOGRAPHY}

Botstein, Leon, 'Songs without Words: Thoughts on Music, Theology, and the Role of the Jewish Question in the Work of Felix Mendelssohn', The Musical Quarterly 77:4 (Winter 1993).

Botstein Leon, 'The Aesthetics of Assimilation and Affirmation: Reconstructing the Career of Felix Mendelssohn' in R. Larry Todd, ed., Mendelssohn and His World (Princeton: Princeton University Press, 1991).

Botstein, Leon, 'Mendelssohn and the Jews', The Musical Quarterly 82:1 (Spring 1998).

Cohen, Shaye J.D., The Beginnings of Jerwishness: Boundaries, Varieties, Uncertainties (Berkley: University of California Press, 1999).

Devrient, Eduard, Meine Erinnerungen an Felix Mendelssohn (Leipzig: J.J. Weber, 1872).

Hensel, Sebastian, The Mendelssohn Family, trans. Carl Klingemann, second edition (New York: Harper, 1882).

Jacob, Heinrich E., Felix Mendelssohn and His Times, trans. Richard and Clara Winston (New Jersey: Prentice Hall, 1963).

Krausz, Michael, 'On Being Jewish' in David Theo Goldberg and Michael Krausz, eds., Fewish Identity (Philadelphia: Temple University Press, 1993).

Langton, Daniel R., The Apostle Paul in the Jewish Imagination (Cambridge: Cambridge University Press, 2010).

Mendelssohn-Bartholdy, Felix, Paulus (Bonn: N. Simrock, 1836).

Mendelssohn, Felix, St. Paul (Birmingham: 1837).

Mendelssohn, Moses, Phaedon or the Death of Socrates (London: J. Cooper, 1789).

Mendelssohn, Moses, Ferusalem or On Religious Power and Fudaism, trans. Allan Arkush (New England: Brandeis, 1983).

Schneider, M., Mendelssohn oder Bartholdy? (Basel: Internationale Felix-Mendelssohn-Gesellschaft, 1962).

Sposato, Jeffrey S., 'Creative Writing: The [Self-] Identification of Mendelssohn as a Jew', The Musical Quarterly 82:1 (Spring 1998).

Sposato, Jeffrey S., 'Mendelssohn, 'Paulus', and the Jews: A Response to Leon Botstein and Michael Steinberg', The Musical Quarterly 83:2 (Summer 1999).

Sposato, Jeffrey, The Price of Assimilation: Felix Mendelssohn and the Nineteenth-Century Anti-Semitic Tradition (Oxford: Oxford University Press, 2006).

Steinberg, Michael P., 'Mendelssohn's Music and German-Jewish Culture: An Intervention', The Musical Quarterly 83:1 (Spring 1999).

Todd, R. Larry, Mendelssohn: A Life in Music (Oxford: Oxford University Press, 2003).

Wagner, Richard, Fudaism in Music and other Writings, trans. W. Ashton Ellis (London: University of Nebraska Press, 1995).

Werner, Eric, A New Image of the Composer and his Age, trans. Dika Newlin (New York: Collier-Macmillan, 1963). 